\title{
PREVALENCE AND COSTS OF HEADACHES FOR THE PUBLIC HEALTH SYSTEM IN A TOWN IN THE INTERIOR OF THE STATE OF SÃO PAULO
}

\author{
Marcelo E. Bigal', Janaína O.M. Bigal', Carlos A. Bordinß̈, José G. Speciali
}

\begin{abstract}
Despite the high prevalence, impact and economic importance of headaches, studies on this subject are rare in Brazil. The aim of the present study was to estimate the prevalence of headaches in the public health system of a town in the interior of the State of São Paulo, as well as to estimate the costs resulting from its management. Data refer to the year of 1998 and were obtained according to the following steps: 1) territorial and demographic characterization of the municipality; 2) characterization of the financial indices and social well-being; 3 ) budget characteristics of the municipality; 4) evaluation of the structuring of the medical service; 5) determination of the prevalence of headaches at different patient care levels; and 6) calculation of the costs of headaches. Headaches represented $7.9 \%$ of all visits at basic health units, $9.7 \%$ in the emergency room and $1.1 \%$ of hospital admissions. The total costs were $\mathrm{R} \$ 85,131.31$ (US\$ 70,942.76) corresponding to $\mathrm{R} \$ 7.59$ (US\$ 6,32) per inhabitant/year. The present study shows the need for epidemiological and economic impact studies, which would provide the basis for the rational use of health funds.
\end{abstract}

KEY WORDS: headache, prevalence, costs.

Prevalência e custos das cefaléias para o Sistema Público de Saúde de uma cidade do interior do Estado de São Paulo

\begin{abstract}
RESUMO - Apesar da grande prevalência, impacto e importância econômica das cefaléias, são incomuns os estudos referentes a esses aspectos em nosso meio. 0 presente estudo visa estimar a prevalência das cefaléias no sistema público de uma cidade do interior do Estado de São Paulo, bem como estimar os custos decorrentes de seu manejo. Os dados referem-se ao ano de 1998 e obedeceram às seguintes etapas: 1 - caracterização territorial e demográfica do município; 2 - caracterização de índices financeiros e de bem estar social; 3 características orçamentárias do município; 4 - avaliação da estruturação do atendimento médico; 5 levantamento da prevalência das cefaléias nos diversos níveis de atendimento; 6 - cálculo dos custos das cefaléias. Cefaléias foram responsáveis por 7,9\% dos atendimentos em unidades básicas de saúde, 9,7\% em pronto socorro e 1,1\% das internações hospitalares. Os custos totais foram de $\mathrm{R} \$ 85.131,31$ (US\$ 70,942.76) o que equivale a R\$7,59 (US\$ 6,32) por habitante/ano. Esse estudo demonstra a necessidade da realização de trabalhos epidemiológicos e de impacto econômico que permitam racionalizar o emprego de verbas para a saúde.
\end{abstract}

PALAVRAS-CHAVE: cefaléia, prevalência, custos.

Headache, defined as all painful processes occurring in the head, is one of the most prevalent symptoms in the population. Its importance can be illustrated by the following data: 1 . Rassmussen et al. (1991) estimated the prevalence of headache throughout life as $93 \%$ among men and $99 \%$ among women ${ }^{1} ; 2$. Between 5 and $10 \%$ of the population intermittently seek medical assistance due to headache $^{2} ; 3$. About $76 \%$ of women and $57 \%$ of men have at least one episode of headache per month';
4. About $40 \%$ of the North-American population have, at some time during their life, headache of an intensity sufficient to lead them to seek medical assistance ${ }^{3}$.

It is known that headache has a considerable impact on the life of affected individuals, both in terms of reduced capabilities and quality of life ${ }^{4}$. Migraine, for example, has been considered to be more incapacitating than depression, osteoarthritis, diabetes, arterial hypertension, and backache ${ }^{5}$. In

\footnotetext{
${ }^{1}$ Master's in Neurology, Faculdade de Medicina de Ribeirão Preto da Universidade de São Paulo, Ribeirão Preto SP, Brazil (FMRP/USP); ${ }^{2}$ Psychology Student, Universidade de Ribeirão Preto (UNAERP); ${ }^{3} \mathrm{MD}$, PhD, Neurologist FMRP/USP; ${ }^{4}$ Associate Professor of Neurology FMRP/USP.
}

Received 2 February 2001, received in final form 18 April 2001. Accepted 23 April 2001. 
addition to affecting the quality of life of sufferers, headache is also known to have a significant economic impact. The concept of the cost of a disease derives from the perception that each illness creates a burden on the patient, his family and society. Analysis of the cost of diseases have been carried out in an attempt to standardize and quantify this burden and to express it in monetary terms. Direct costs include medical care (diagnosis, treatment, medication, and other costs such as transport and special equipment) and may have repercussion on the patient (in the case of private health care) or on the state (public health care). Indirect costs are measured in terms of the value of lost production attributable to the illness, including the loss of salary and an estimate of the value of domestic services. The reduction in work effectiveness should also be measured and analyzed. Other indirect costs include fewer opportunities for promotion and education, the patient having to make changes in occupation which were not intended, and the time lost by persons accompanying the patient. The aggregate cost includes expenses for medical research, professional training, construction of buildings, and service administration. In fact, some costs such as those of basic research are difficult to evaluate ${ }^{6-8}$. Considering only the costs of migraine in the United States, studies have evaluated the annual direct cost to be 9.6 billion dollars ${ }^{9}$. Estimates of indirect costs range from 1.4 to 17.2 billion dollars ${ }^{10}$. A study carried out by our group estimated that the University Hospital of Ribeirão Preto, Brazil, lost $\mathrm{R} \$ 986,000$ in a single year just due to the reduced productivity of the workers during a migraine crisis ${ }^{11}$.

Despite the high prevalence, impact and economic importance of headaches, studies on this subject are rare in Brazil. The objective of the present study was to estimate the prevalence of headaches in the public health units of a town in the interior of the State of São Paulo, as well as to estimate the resulting management costs. An additional objective was to obtain a correct sociodemographic characterization of the municipality in such a way that it would permit eventual future extrapolation of the data to similar localities.

\section{METHOD}

The study was carried out in the town of Ipuã, located in the interior of the State of São Paulo, with an estimated population of 11,208 inhabitants. Data refer to the year 1998 and were obtained according to the following steps:

i - Demographic and territorial characterization of the municipality. The data sources were: A) Geographic and
Cartographic Institute - 1998 Annual Report ${ }^{12}$, B) Brazilian Institute for Geography and Statistics - 1998 data $^{13}$; C) State System Foundation for Data Analysis $(\mathrm{SEADE})^{14}$, and D) Municipal Health Profile - SEADE, $1999^{15}$. The data obtained during this and the following steps were compared with those obtained for the State of São Paulo in order to adequately determine the position of the town in terms of demographic, economic and social characteristics.

ii - Characterization of financial indices and social wellbeing. In addition to the data sources mentioned under item i, information was obtained directly from the Department of Health and the Finance Sector of the Town Hall of Ipuã for this and the following items.

iii - Budget characteristics of the municipality.

iv - Estimation of the structuring of the outpatient and emergency medical services of the town.

$v$ - Determination of the prevalence of headaches at the different patient care levels. For this purpose, all diagnostic records of the patients were reviewed by the informatics department of the municipality. These data concern only Ipuã inhabitant patients. In the municipality of Ipuã, physicians fill out a field on the visit card for any type of care provided, indicating the diagnosis which then is transcribed to spreadsheets. Therefore, using these spreadsheets tabulated by the informatics service, we initially considered all diagnosis which were referring to cases of patients who looked for the health service with headache being the main complaint (ranging from headache to be clarified, migraine, and sinusitis to other diagnoses such as a hypertensive crisis and flu). After this initial screening, we studied the records of these patients and considered only those cases who effectively sought the health service because of headache. Cases of cranial trauma and acute polytraumatism were excluded.

vi - Costs of headache. We calculated the following costs:

A)- Costs of care at the health units. We used a methodology analogous to that employed by institutions such as the University Hospital of Ribeirão Preto ${ }^{16}$, which consisted of dividing the funds used during a given period for managing this service level by the number of visits performed during the same period. Multiplying this value by the number of visits results in the value spent for a given illness.

B)- Costs of emergency care. The same method as described above was used.

C)- Costs of hospital admissions. The number of admissions per year was determined, followed by the number of hospitalization days resulting from these admissions. Further procedures were as described under the items above.

D)- Costs of emergency referral. The town hall provided the estimates of the medical costs of emergency referral which were made by ambulances and which were the responsibility of the local Santa Casa hospital. This 
value was multiplied by the number of referrals per year due to headache.

E)- Costs of elective referral. The costs of these referrals, made by bus (under responsibility of the Social Fund of the town), were calculated in a similar manner as described for item $D$.

The conversion to US\$ was made according the 1998 year medium exchange ( 1 US $\$=1,20 R \$$ ).

This study has been the approval of the Department of Health of the Town Hall of Ipuã.

\section{RESULTS}

$i$ - The data concerning territorial and demographic characterization of the municipality are shown in Table 1 and were compared with those of the State of São Paulo. The distribution of the population according to age and gender is shown in Fig 1. ii - The financial indices and social well-being are shown in Table 2. The family head's income, shown in Figure 2, is usually considered a good standard for the evaluation of the economic level of a given population.

iii - The budget characteristics of the municipality are shown in Table 3. These data do not include expenses with the Santa Casa hospital which has its own budget. Total health expenses include the resources of the municipality itself and those allocated by the Unified Health System (UHS). The town does not receive other financial aid, i.e., federal, state, or university aid, for the health sector.

iv - Evaluation of the structuring of outpatient and emergency medical care. The municipality has three basic health units (BHU), one emergency room service (ER) and one hospital (Santa Casa). The flow chart of care is shown in Fig 3.

Table 1. Demographic and territorial characterization of the town of Ipuã and the State of São Paulo.

\begin{tabular}{lcc}
\hline Variable & Ipuã* & State of São Paulo* \\
\hline Territorial area $\left(\mathrm{km}^{2}\right)$ & 564 & 248,600 \\
Demographic density (inhab/ km²) & 19.47 & 137.07 \\
Geometric rate of annual population growth & 1.53 & 1.4 \\
Urbanization index & 92.07 & 93.11 \\
Population (1998) & 11,208 & $34,076,644$ \\
Males (\%) & 51.3 & 49.11 \\
Females (\%) & 48.7 & 50.89 \\
Birth rate (per 1000 inhabitants) & 20.58 & 20.24 \\
Number of stillbirths (per 1000 inhabitants) & 4.41 & 10.66 \\
General fecundity rate & 70.66 & 76.35 \\
\hline
\end{tabular}

* Source: references 12 and 13 .

Fig 1. Distribution of the population of the town of Ipuã, according to age and gender.

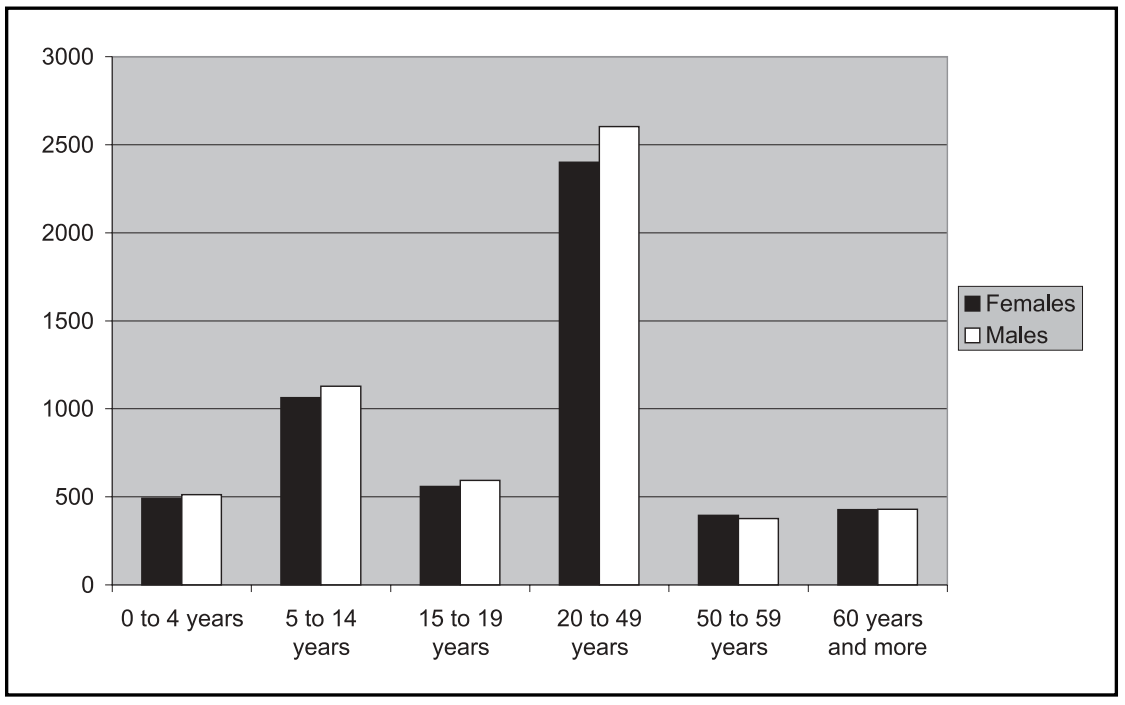




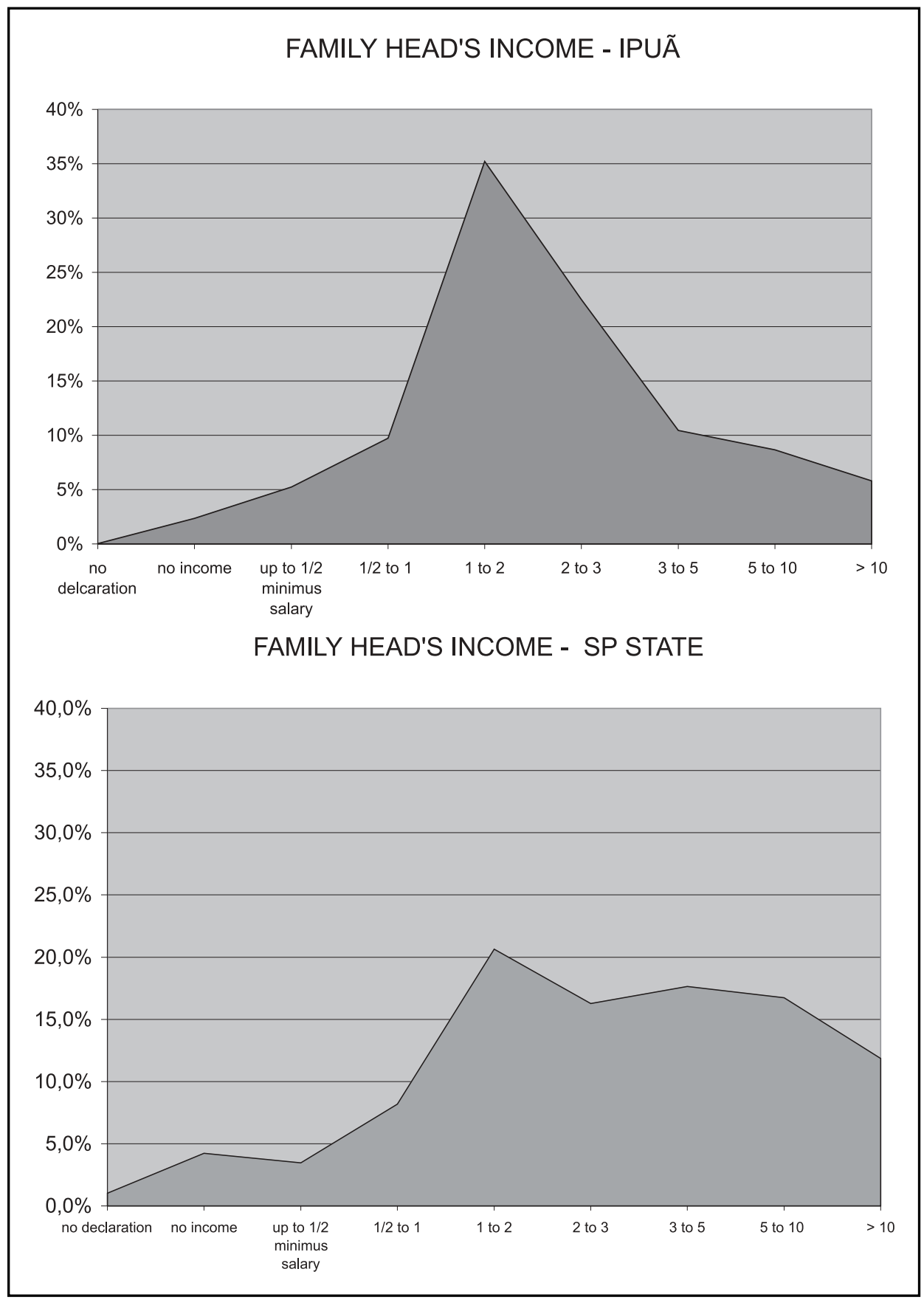

Fig 2. Income of family heads in Ipuã and in the State of São Paulo.

v - Percentile and costs of patients who seek BHU and ER with headaches as the major complaint. These data are shown in Table 4.

vi - Percentile and costs of patients who seek the Santa Casa hospital with headache as the major complaint. Santa Casa is the only hospital in the town and is responsible for all hospital admissions. A total of $63.64 \%$ of the admissions in 1998 were patients from the UHS and the remaining ones were private patients or those with medical insurance. In 1998, there were 701 UHS admissions, corresponding to 2,536 pa-
Table 2. Indices of social well-being.

\begin{tabular}{lcc}
\hline Variable & Ipuã* & $\begin{array}{c}\text { State of } \\
\text { São Paulo* }\end{array}$ \\
\hline Territorial area $\left(\mathrm{km}^{2}\right)$ & 564 & 248,600 \\
Illiteracy rate among adults & $18.97 \%$ & $11.28 \%$ \\
Illiteracy among fertile women & $11.49 \%$ & $6.57 \%$ \\
Level of water supply & $97.91 \%$ & $96.39 \%$ \\
Level of sewage service & $87.84 \%$ & $80.83 \%$ \\
Level of garbage collection & $94.25 \%$ & $96.15 \%$ \\
\hline
\end{tabular}

* Source: references 12 and 13 . 
Table 3. Budget characteristics of the town of Ipuã.

\begin{tabular}{lc}
\hline Variable & $\begin{array}{c}\text { Value * } \\
\mathrm{R} \$(\text { US } \$)\end{array}$ \\
\hline Total revenue of the town & $\begin{array}{r}6,450,465.72(5,375,388.10) \\
1,583,819.04(1,319,349.20)\end{array}$ \\
Total health expenses of the town hall & $1,439,813.04(1,199,844.20)$ \\
Health expenses using the town's own resources & $144,006.00(120,005.00)$ \\
Health expenses using UHS resources & $24.5 \%$ \\
Health expenses (\% of total town revenue) & $141.31(117.76)$ \\
\hline Health expenses per year per inhabitant &
\end{tabular}

UHS: Unified Health System; * Source: References 14 and 15.

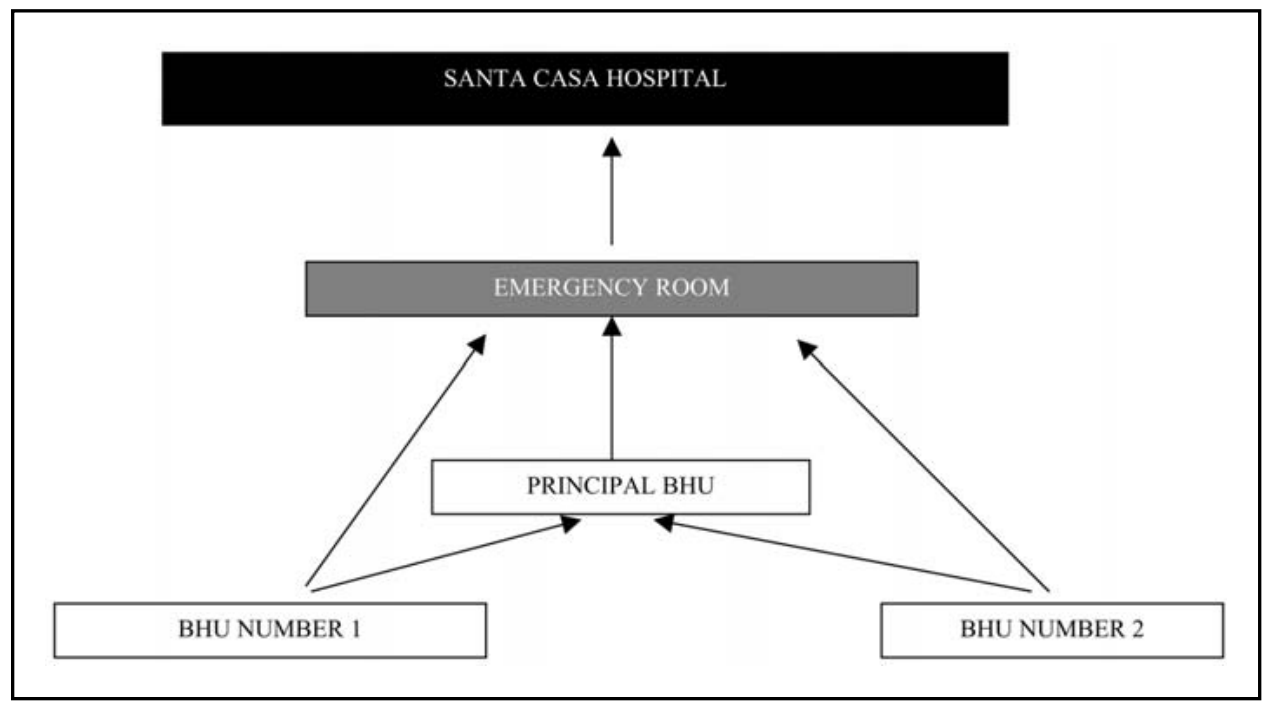

Fig 3. Flow chart of health services in the town.

tients/day (days of hospitalization). Eight admissions during this year were due to headache ( 3 cases of meningitis with headache being the main complaint and 5 with other causes), totaling 41 days of hospitalization. The costs of the Santa Casa hospital are detailed in Table 5. As shown in the table, the hospital had expenses of the order of $R \$ 470,841.57$ (US\$ $392,367.97$ ) in 1998. Of these, $\mathrm{R} \$ 355,858.000$ (US\$ $296,548.33-75.6 \%$ ) were spent in the area of social assistance, with this amount being effectively spent on health. The remaining amount was used for debt remanagement and others. Therefore, the cost of one day of hospitalization at Santa Casa is R\$140.32 (US\$116,93). In one year, 8 patients were admitted due to headache ( $1.1 \%$ of total admissions), corresponding to 41 days of hospitalization ( $1.6 \%$ of the total) with an annual admission cost of $R \$ 5,753.22$ (US\$ 4,794.35). vii - Emergency referrals. Emergency referrals to other towns are the responsibility of Santa Casa. The mean cost of referrals (considering the salary of the driver, fuel, social security and others) was $\mathrm{R} \$$ 27.48 (US\$22,90) - estimate provided by the hospital). In 1998, 23 patients with headache were referred, with a cost of $R \$ 632,04$ (US\$519,20).

viii - Elective referrals. The expenses with elective referrals, which are the responsibility of the town hall, were not computed as health expenses because they are under the responsibility of the Social Assistance Fund of the municipality. Patients travel by bus at an estimated cost of $R \$$ 8.15 (US\$ 6,79) per trip. In 1998, 12 headache follow-up patients were counted in the city of Franca (39 trips per year) and 9 in Ribeirão Preto (36 trips per year), totaling 75 trips at a cost of $\mathrm{R} \$ 611.25$ (US\$ 509,37).

ix - Total costs are shown in Table 6. Expenses of the town with headache were of the order of 
Table 4. Absolute value, percentile and costs of headaches at the different service levels.

\begin{tabular}{lccccc}
\hline Type of service & Visits/year & $\begin{array}{c}\text { Expenses per } \\
\text { visit R\$ (US\$) }\end{array}$ & $\begin{array}{c}\text { Visits per } \\
\text { headache }\end{array}$ & $\begin{array}{c}\text { \% Visits per } \\
\text { headache }\end{array}$ & $\begin{array}{c}\text { Total cost of headache } \\
\text { R\$ (US\$) }\end{array}$ \\
\hline BHU - Internal medicine & 10,392 & $27.48(22.90)$ & 759 & $7.30 \%$ & $20,857.32(17,381.10)$ \\
BHU - Pediatrics & 4,620 & $27.48(22.90)$ & 236 & $5.10 \%$ & $6,485.28(5,404.40)$ \\
BHU - Gynecology & 2,024 & $27.48(22.90)$ & 140 & $6.90 \%$ & $3,847.20(3,206.00)$ \\
BHU - Others & 3,276 & $27.48(22.90)$ & 300 & $9.20 \%$ & $8,244.00(6,870.00)$ \\
Emergency room & 9,747 & $45.80(38.17)$ & 945 & $9.70 \%$ & $38,701.00(32,250.33)$ \\
Total & 30,059 & & 2,380 & $7.90 \%$ & $78,134.80(65,112.33)$ \\
\hline
\end{tabular}

BHU: basic health units.

Table 5. Spreadsheet of expenses of Santa Casa de Ipuã in 1998.

\begin{tabular}{lc}
\hline Variable & Total R\$(US\$) \\
\hline Salary & $150,771.58(125,642.98)$ \\
13th salary & $11,871.85(9,893.21)$ \\
Holidays & $12,595.15(10,495.96)$ \\
Welfare & $14,635.80(12,196.50)$ \\
FGTS & $20,039.34(16,699.50)$ \\
Medication & $20,050.73(16,708.94)]$ \\
Consumables & $7,646.16(6,371.80)$ \\
Energy & $7,666.10(6,388.41)$ \\
Telephone & $4,065.70(3,388.08)$ \\
Office hours & $3,169.71(2,641.42)$ \\
Food & $7,037.81(5,864.84)$ \\
Fuel & $1,978.99(1,649.16)$ \\
Transportation & $110.79(92,32)$ \\
Refreshments and meals & $115.00(95,83)$ \\
Cleaning & $4,240.86(3,534.05)$ \\
Laboratory exams & $1,699.52(1,416.27)$ \\
Others & $4,573.49(3,811.24)$ \\
PIS (trabalhist tribute) & $1,650.31(1,375.26)$ \\
Other medical funds allotted & $1,767.48(1,472.90)$ \\
Persons on duty & $183,606.82(153,005.68)$ \\
Medical funds allotted & $11,548.28(9,623.57)$ \\
Total & $470,841.57(393,367.97)$ \\
\hline & \\
&
\end{tabular}

$\mathrm{R} \$ 78,406.05$ (US\$ 65,338.57), corresponding to R\$ 7.02 (US\$ 5.85) per inhabitant/year. The expenses of Santa Casa with UHS patients were $\mathrm{R} \$ 6,385.36$ (US\$ 5,321.13) or R\$ 0.57 (US\$ $0,48)$ per inhabitant/year. The total cost of headache was R\$ 7.59 ( US\$ 6,33) per inhabitant/ year.
Table 6. Total costs generated by patients with headache in 1998.

\begin{tabular}{lc}
\hline Service & Total R\$ (US\$) \\
\hline BHU visits & $39,433.80(32,861.50)$ \\
Emergency room visits & $38,701.00(32,250.83)$ \\
Hospital admissions & $5,753.22(4,794.35)$ \\
Emergency referrals & $632.04(526.70)$ \\
Elective referrals & $611.25(509.37)$ \\
Total & $85,131.31(70,942.76)$ \\
\hline
\end{tabular}

\section{DISCUSSION}

Despite the high prevalence of headaches in the population and its elevated impact on the public health system, studies in Brazil on this subject are extremely rare, which certainly is a contradiction, especially considering that Brazil is a developing country suffering from a lack of health funds, and therefore requires a better rationalization of available funds. For example, there are no national population studies on the prevalence of headaches.

Since headache has a high prevalence and imposes a significant burden on the affected individuals, it certainly has repercussions on the health system. A study by our group showed that $9.3 \%$ of all adult visits at the UHS were due to headache ${ }^{17}$ and 1254 patients with acute headache were seen at the Emergency Unit of the University Hospital of Ribeirão Preto in a single year ${ }^{18}$, numbers similar to those observed at other Brazilian emergency services ${ }^{19}$. Other national studies have shown that headache is the third cause of general clinical outpatient visits and the first cause of neurology outpatient visits ${ }^{20}$.

Despite the data reported above, there are no national studies on the impact of headaches on the 
public health service. Therefore, one of the main concerns of the present study, in addition to effectively evaluating the impact and the management costs for the health system, was to obtain a correct geographic, demographic and socioeconomic characterization of the municipality. We considered this step indispensable since it would permit the extrapolation of given data to towns and communities with similar characteristics. Considering the size of Brazil and of the State of São Paulo and the resulting difficulties for performing this type of study, a well-conducted extrapolation may permit the estimation of reasonably approximated costs.

The characterization of the municipality (Tables 1 and 2, and Fig 1) followed the recommendations of the Brazilian Institute for Geography and Statistics $^{13}$, including those adopted for population samples at the time of decennial censuses. Analysis revealed a small town of 11,208 inhabitants, with a predominantly urban character (an urbanization index of $92.07 \%$ similar to the $93.11 \%$ index for the State of São Paulo). The town represents a typical small "paulista" town, which differs from other towns of similar size from other Brazilian states in terms of the high urbanization index. The population predominantly consists of young and middle-age persons and the indices of social well-being show an illiteracy rate higher than the mean rate for the State and highly similar to those of other towns of the same size. The family head's income (Fig 2) is a parameter that is considered quite reliable for the economic characterization of a locality since, in contrast to per capita income, it permits the visualization of income distribution. The town predominantly consists of low-income families, with the curve shifted to the left in relation to that obtained for the State, but superimposable in relation to towns of the same size. We therefore believe that the community is representative of other communities of the same size in the State of São Paulo but not of Brazilian communities in general.

The budget characteristics of the municipality are shown in Table 3. Health expenses represented $25.4 \%$ of the expenses of the municipality, corresponding to $\mathrm{R} \$ 141.31$ (US\$117,56) per inhabitant during the period studied. This expense was highly significant, since, for the sake of comparison, the latest data available for the municipalities of Ribeirão Preto and São Paulo (1995), ${ }^{14,15}$ were R\$ 78.15 (US\$ 65,13) and $\mathrm{R} \$ 67.94$ (US\$56,62), respectively.

The structuring of the public health system of the municipality (Fig 3 ) is simple and facilitated the cal- culation of the prevalence and costs of headaches. The town has three BHU, one ER and one hospital and the patients therefore have to follow the flow chart of care shown in Fig 3.

The prevalence of headaches in the BHU ranged from 5.1 to $9.2 \%$ according to the outpatient clinic studied, a value similar to the $9.3 \%$ prevalence observed by our group in another study evaluating the $\mathrm{BHU}$ of medium-sized cities ${ }^{17}$ and to the $10.3 \%$ prevalence obtained in a study conducted in the city of São Paulo20, indicating agreement between different studies carried out in Brazil on the prevalence of headaches in BHU. The prevalence of headache was $7.9 \%$ in the emergency room and $1.1 \%$ in the hospital. Most studies have shown that headaches represent 1 to $3 \%$ of hospital services ${ }^{21-23}$. The value observed for the Emergency Unit of the University Hospital of Ribeirão Preto was $0.5 \%{ }^{18}$.

There are different ways to calculate the costs of medical procedures, all of them subject to criticism. For example, one way is to use the procedure table of the UHS. In this way, each visit and procedure is calculated according to the table, which, however, is known to be out of phase with an important part of medical actions and therefore not representative of the real costs, with the revision of the table even being one of the greatest claims of the towns to the Federal Government. A second way is to sum the costs of procedures using a usually accepted cost table (ABIFARMA and the Hospital Association). This methodology can be also criticized since it does not consider some differential factors, i.e., the number of paramedics does not influence the cost of the daily hospital rate, and expenses for structural reforms and similar expenses are not included in the calculation.

Therefore, the town of Ipuã, like other town and large institutions such as the University Hospital of Ribeirão Preto ${ }^{16}$, chooses to calculate the value of a visit by dividing the value necessary to perform a visit (i.e., maintenance of the physical area, reforms, salaries of doctors and paramedics, medication and others) by the number of visits during a given period of time. This method was also used by the Santa Casa hospital of the town (Table 5). This methodology can certainly cause great distortions when used in highly complex units (since it equalizes, for example, the value of an oncology visit and that of a pediatric visit), but it seems quite adequate for use in basic health units and small hospitals, where the degree of complexity is lower and, therefore, the above described bias is reasonably small. We believe 
that this methodology is the one mostly reflecting the real costs in situations such as those studied here.

The expenses for headaches of the order of $R \$$ 7.59 (US\$ 6,32) per inhabitant/year, as shown in Tables 4 and 6, were highly significant, corresponding to $5.4 \%$ of the annual health budget, with this value being higher than that applied to preventive medicine (5.1\%). However, these data are still an underestimate of the costs of headaches since they do not consider the costs of visits carried out in towns to which patients have been referred nor other aspects such as the donation of medicines to patients in need by the Solidarity Fund. We believe that the cost of headaches is still higher than that obtained in the present study.

The search for rationality in health expenses has been announced as the goal by most public and private managing agencies. In Brazil, these affirmations collide with the lack of effectively conducted epidemiological studies, and studies on the impact on life quality and their costs ${ }^{24}$. These studies should be carried out and corrective measures should be implemented as soon as possible, especially in developing countries where the available resources are smaller than the necessities of the population.

\section{REFERENCES}

1. Rasmussen BK, Jansen R, Olesen J. A population-based analysis of the diagnostic criteria of the International Headache Society. Cephalalgia 1991;11:129-134.

2. Rasmussen BK. Epidemiology of headache. Cephalalgia 1995;15:45-68.

3. Speciali JG. Simpósio Cefaléia: introdução. Medicina Ribeirão Preto 1997;30: 419-420.

4. Michel MD, Dartigues JF, Lindouisi MD. Loss of productivity and quality of life in migraine sufferers among French workers: results from the GAZEL cohort. Headache 1997;37:71-78.
5. Solomon GD, Skobieranda FG, Gragg L. Quality of life and well-being of headache patients: measurements by the Medical Outcome Study Instrument. Headache 1993;33:351-358.

6. Bordini CA. Impacto na vida diária causado pela enxaqueca. In Anais do Simpósio Internacional de Cefaléia, São Paulo, 1998.

7. De Lissovoy G, Lazarus SS. The economic cost of migraine. Present state of knowledge. Neurology 1994;44(suppl 4):56-62.

8. Kamlet MS, Wade M, Kupfer DJ et al. Cost-utility analysis of maintenance treatment for recurrent depression: a theoretical framework and numerical illustration. In: Frank, R. Economics and mental health. Baltimore: Johns Hopkins Univ Press, 1992,265-291.

9. Ferrari MD. The direct cost of migraine to society. In Assessing migraine disability and optimizing care: a poster presentation. Migraine disability assessment programme, sponsored by Zeneca Pharmaceuticals, 1998:5.

10. Stewart WF, Lipton RB. The indirect cost of migraine to society. In Assessing migraine disability and optimizing care: a poster presentation. Migraine disability assessment programme, sponsored by Zeneca Pharmaceuticals, 1998:6.

11. Bigal ME, Bordini CA, Speciali JG. Custos indiretos da migrânea em um hospital público brasileiro. Headache (in press).

12. Anuário Estatístico do Instituto Geográfico e Cartográfico. Governo do Brasil, 1998.

13. Fundação Instituto Brasileiro de Geografia e Estatística. Governo do Brasil, 1998.

14. Fundação Sistema Estadual de Análise de Dados (SEADE). Secretaria da Economia e Planejamento, Governo do Estado de São Paulo, 1998.

15. Perfil Municipal de Saúde - SEADE. Secretaria da Saúde, Governo do Estado de São Paulo, 1998.

16. Anuário Estatístico do Hospital das Clínicas da Faculdade de Medicina de Ribeirão Preto - USP. Superintendência do HC - FMRP - USP, 1996.

17. Bigal ME, Bordini CA, Speciali JG. Etiology and distribution of headaches in two Brazilian primary care units. Headache 2000;40:248-251.

18. Bigal ME, Bordini CA, Speciali JG. Headache in an Emergency Room. São Paulo Med J 2000;3:74-79.

19. Zukerman E, Lima JGC, Hannuch SNM, et al. Unidade de atendimento de agudos com cefaléia (UAAC): uma experiência nova em nosso meio. Rev Ass Med Bras 1989;35:107-110.

20. Ferri-de-Barros JE, Nitrini R. Que pacientes atende um neurologista? Alicerces de um currículo em Neurologia. Arq Neuropsiquiatr 1996;54:637-644.

21. Olesen J, Aebelholt A, Veilis, B. The Copenhagen acute headache clinic: organization, patient material and treatment results. Headache. 1978;19:223-227.

22. Leicht MJ. Non-traumatic headache in the emergency department. Ann Emerg Med. 1980;9:404-409.

23. Welch KMA. Headache in the Emergency Room. In The headaches. Olesen J, Tfelt-Hansen P, Welch KMA (eds). New York: Raven Press, 1993.

24. Vincent, MB, Rodrigues, AJ, Oliveira, GV, et al. Prevalência e custos indiretos das cefaléias em uma empresa brasileira. Arq Neuropsiquiatr 1998;56:734-743. 